\title{
Towards a relevance-theoretic approach to the diminutive morpheme ${ }^{1}$
}

\author{
Manuel PADILLA CRUZ \\ University of Seville \\ Seville, Spain
}

\begin{abstract}
This paper intends to lay the foundations for a relevance-theoretic approach to the diminutive morpheme. In many languages, this morpheme is attached to nouns, adjectives, adverbs or verbs. It frequently nuances their referents by providing information concerning the smallness, littleness or scarcity of the size, amount or degree of their referents. However, the semantics of this morpheme cannot always be connected with such notions. In Spanish, for example, it is often used in order to intensify, express approximation or pejoration, show affection or modesty, suggest intimacy or mitigate verbal actions. This variety of functions renders its semantics fairly elusive and rules out a conceptual analysis. Relying on the relevance-theoretic distinction between conceptual and procedural meaning, this paper argues that the diminutive might possess a procedural semantics amounting to procedures or processing instructions. It also considers the output(s) of such procedures in Spanish and shows that in several cases the diminutive would clearly contribute to the lexical pragmatic processes taking place during mutual parallel adjustment. These yield highly idiosyncratic conceptual representations. In other cases, the instructions encoded by the diminutive could be thought to trigger a representation of the speaker's psychological states or even contribute to what in relevance-theoretic pragmatics is known as the higher-level explicature of an utterance. Since this would involve admitting that the semantics of the diminutive could be poly-procedural, this paper concludes by wondering whether a unitary procedural approach would be preferable.
\end{abstract}

Keywords: diminutive morpheme, relevance theory, procedural meaning, lexical pragmatics, ad hoc concepts, higher-level explicatures

\section{For citation:}

Padilla Cruz, Manuel. 2020. Towards a relevance-theoretic approach to the diminutive morpheme. Russian Journal of Linguistics 24 (4). 774-795. DOI: 10.22363/2687-0088-2020-24-4774-795

${ }^{1}$ Some of the ideas presented in this paper are also discussed in another article (Padilla Cruz, in press). This work has been funded by the research project "La formación de la conciencia figurativa en la etapa de Educación Primaria: el humor y la fraseología" (FFI2016-76047-P), funded by the Spanish Research Agency of the Ministry of Economy, Industry and Competitivity. 
Научная статья

\title{
Рассмотрение морфем с уменьшительным значением в рамках теории релевантности
}

\author{
Мануэль ПАДИЛЬЯ КРУЗ \\ Севильский университет \\ Севилья, Испания
}

\begin{abstract}
Аннотация
Цель статьи - заложить основу рассмотрения морфем с уменьшительным значением в рамках теории релевантности. Во многих языках эти морфемы присоединяются к существительным, прилагательным, наречиям или глаголам. Они часто придают референциальному значению оттенок, указывающий на маленький размер, небольшой объем или незначительную степень выраженности признака. Однако семантика данных морфем не всегда может быть соотнесена с этими понятиями. Например, в испанском языке они часто выражают интенсивность, приблизительность, уничижение, обозначают любовь или скромность, указывают на близость или смягчают глагольные действия. Это разнообразие функций делает семантику морфемы трудноуловимой и затрудняет ее понятийный анализ. Опираясь на разграничение понятийного и процедурного значения с точки зрения теории релевантности, автор статьи утверждает, что диминутив может обладать процедурной семантикой, выражающей процедуру или команду по обработке информации. В статье также рассмотрены результаты таких процедур в испанском языке и показано, что в некоторых случаях диминутив вносит очевидный вклад в лексико-семантические процессы, происходящие во время взаимного параллельного приспособления. Результатом этих процессов становятся идиосинкретические понятийные репрезентации. В других случаях инструкции, закодированные в диминутиве, могут служить источником репрезентаций психологического состояния говорящего или даже вносить вклад в то, что в прагматике теории релевантности известно как экспликатура высшего уровня в высказывании. Исследование свидетельствуют о том, что семантика диминутивов может быть полипроцедуральной, и ставит вопрос о предпочтительности унитарного процедурального подхода к их исследованию.
\end{abstract}

Ключевые слова: диминутив, теория релевантности, процедурное значение, лексическая прагматика, ситуативные понятия, высокоуровневая экспликатура

\section{Для цитирования:}

Padilla Cruz M. Towards a relevance-theoretic approach to the diminutive morpheme. Russian Journal of Linguistics. 2020. Vol. 24. № 4. P. 774-795. DOI: 10.22363/2687-0088-2020-24-4774-795

\section{Introduction}

Morphemes are linguistic units that are added to stems in different positions. They are traditionally defined as the smallest elements endowed with meaning, so they modify the meaning of the stems receiving them. Inflectional languages possess a wide variety of them, among which is the diminutive. This is classified as a derivational morpheme that tends to indicate an objective appraisal pertaining to smallness, littleness or scarcity. However, it can also convey more subjective assessments. As a result, the diminutive is normally regarded as an evaluative morpheme (Volek 1987, Wierzbicka 1991, Bosque 2009). 
In addition to its evaluative function, the diminutive fulfils other functions in various languages. In Spanish, for instance, these include intensification, approximation and pejoration (Mendoza 2005). In certain social contexts characterised by good, friendly relationships, it may also express attitudes and feelings like affection or endearment, as well as a range and shades of positive and negative emotions. This likewise enables it to suggest, assert or highlight intimacy between the interlocutors, and even facilitates its use to insult mildly in joking or playful situations (Mendoza 2005, Náñez Fernández 2006, Maíz-Arévalo 2018). Furthermore, the diminutive can frequently be employed with completely diverse functions when any of the interlocutors' face is at risk (Brown and Levinson 1987). On the one hand, it may work as a device enabling the speaker ${ }^{2}$ to avoid bragging and show modesty. On the other hand, it may function as a hedging or mitigating tool permitting her to soften the weightiness or seriousness of certain verbal actions (Garcés Conejos, Bou Franch and García Gómez 1992, Sifianou 1992, De Marco 1995, Albelda Marco and Briz Gómez 2010, Bardaneh 2010, Albelda Marco and Cestera Mancera 2011, Briz Gómez 2011, Briz Gómez and Albelda Marco 2013).

This multi-functionality does not only cause the diminutive to resist a unitary treatment, but even seems to preclude a conceptual analysis. Although it could be stably associated with notions like smallness, littleness or scarcity in some cases, such notional matches seem unlikely in other cases. Still, on some occasions what the speaker means exactly turns out extremely hard to pin down in conceptual terms. If the diminutive did not encode only one concept, or a determinate group of concepts, what would it encode? Moreover, what would it contribute to communication? This paper seeks to begin to search for some answers to these questions. It will do so on the grounds of relevance theory and through examples from Spanish (Sperber and Wilson 1986/1995, Wilson and Sperber 2002, 2004).

Relevance theory is a cognitive-pragmatic framework that centres on comprehension. It portrays this as an exercise in mindreading, or attribution of intentions and psychological states. Among them is the speaker's informative intention, or her intended message(s). Comprehension is driven by expectations of relevance: achieving a satisfactory amount of cognitive benefit in exchange for a reasonable amount of cognitive or processing effort (Wilson 1999, Wilson and Sperber 2002, 2004). It mobilises a set of automatic, specialised and incredibly fast mental mechanisms that perform a number of parallel, non-sequential, subconscious inferential tasks during an intricate process that is termed mutual parallel adjustment. These tasks yield specific outputs that facilitate the formulation of a hypothesis about speaker's meaning. Although some of them are performed by the comprehension mechanism as a necessary step to formulate such a hypothesis, the inferences made in other tasks are determined by (para)linguistic elements of the acoustic signal (Carston 2000, Jary 2016). These elements are considered to

${ }^{2}$ Following a relevance-theoretic convention, reference to the speaker is made through the feminine $3^{\text {rd }}$ person singular personal pronoun, while reference to the hearer is made through the masculine counterpart. 
encode processing instructions or procedures, so their semantics is procedural (Blakemore 1987, 1992, 2002, Wilson and Sperber 1993, Carston 2016, Wilson 2016). This paper will suggest that the diminutive morpheme could also encode procedures and that its contribution to comprehension would hence amount to constraints on (some of) the interpretative tasks performed during mutual parallel adjustment. It will also show that the procedural semantics of the diminutive might be supposed to yield distinct outputs, so it could be regarded as poly-procedural. This would challenge the feasibility of a unitary procedural approach in light of the extant relevance-theoretic conception of procedural meaning (Carston 2016, Wilson 2016).

\section{Functions of the diminutive}

In languages like English the diminutive is frequently conveyed analytically and there are words with a diminutive meaning (Zuluaga Ospina 1970, Schneider 2003). In contrast, in Romance languages like Spanish or Italian, or in languages as diverse as Greek or Jordanian Arabic, to name but a few, it is an affix with a high frequency of occurrence or productivity (Sifianou 1992, De Marco 1995, Bardaneh 2010). In fact, in these languages it is not only attached to nouns, but also to adjectives, adverbs and verbs. In Spanish, furthermore, the diminutive may often be realised through various allomorphs, which are subject to regional or dialectal variation: -ito/a (casita, gordito), -ico/a (perrico, latica), or -illo/a (casilla, mayorcillo), with variation for grammatical gender (Gómez Torrego 2002, Mendoza 2005, Bosque 2009).

As an evaluative morpheme, the diminutive usually expresses objective and subjective judgements concerning the smaller size of the referent of a noun, the lesser amount of the quality denoted by an adjective, or the lower degree of the manner alluded to by an adverb. However, it may also serve distinct purposes. In Spanish these include (Mendoza 2005, Maíz-Arévalo 2018):

a) Intensifying the conditions or states referred to by adjectives or adverbs:

(1) a. La habitación está limpita.

'The room is clean[+DIM]'.

b. Comimos tempranito.

'We ate early[+DIM]'.

b) Making approximate or vague estimates:

(2) a. El pueblo está cerquita.

'The town is closer'.

b. Carmen está agobiadilla con los exámenes.

'Carmen is overwhelmed[+DIM] because of the exams'.

c) Denigrating, deteriorating, disparaging or slighting the referent of nouns:

(3) a. Llevaba una camisilla con unas florecitas espantosas.

'She was wearing a shirt[+DIM] with hideous flowers[+DIM]'. 
b. Pablo es un jovenzuelo de reputación cuestionable.

'Paul is a youngster[+DIM] of questionable reputation'.

The functions of the diminutive are not limited to these, though. It fulfils others that are motivated by the social context wherein interlocutors interact and are linked to the expression of politeness (Brown and Levinson 1987), rapport-management (Spencer-Oatey 2008) or relational work (Locher and Watts 2005). On the one hand, the diminutive works as a positive-politeness strategy aimed at addressing the hearer's positive face, or as a rapport-maintaining or enhancing tactic. It indicates social proximity, solidarity and membership to a same group that shares viewpoints, values, feelings and intentions (Brown and Levinson 1987: 103, Fraser 1990: 230). As a hearer-supportive device, it boosts the force of the utterance while enhancing the hearer's positive face. This is common in positive-politeness contexts characterised by intimacy and good relationships, or, what is the same, in solidarity politeness systems distinguished by social proximity and lack of power differences (Scollon and Scollon 1995). This overall role makes it possible for the diminutive to achieve two crucial goals (Sifianou 1992, Mendoza 2005, Badarneh 2010, MaízArévalo 2018):

d) Showing positive attitudes like affection and endearment towards the hearer or something connected with him, while expressing a wide array and shades of beneficial emotions and feelings. In this case, the diminutive behaves as an expressive (Potts 2007a, 2007b, Blakemore 2011, 2015):

(4) Tienes una casita muy acogedora.

'You own a very cosy house[+DIM]'.

e) Suggesting, asserting or emphasising intimacy and camaraderie in joking or playful situations where the interlocutors can even insult each other mildly:

(5) ¡Eres un cabroncete!

'You are a bastard[+DIM]!'

On the other hand, the diminutive safeguards the interlocutors' face from potential threats (Sifianou 1992, Bosque 2009, Albelda Marco and Briz Gómez 2010, Badarneh 2010, Albelda Marco and Cestero Mancera 2011, Briz Gómez 2011). It may protect the speaker's positive face as long as it enables her to avoid bragging or appearing arrogant, conceited or presumptuous. Hence, by means of it the speaker (f) can show modesty and humility:

(6) Me he comprado un cochecito nuevo.

'I have recently bought a new car[+DIM]'.

Regarding the hearer's face, the diminutive acts as a negative-politeness strategy purporting to not impose on him, but to respect his freedom of action (Brown and Levinson 1987: 129). It attends to his negative face, as long as it mitigates or attenuates the weightiness of an action or what this demands. Therefore, the diminutive $(\mathrm{g})$ hedges speech acts like requests or directives by 
minimizing their rank of imposition (Albelda Marco and Briz Gómez 2010, Briz Gómez 2011, Briz Gómez and Albelda Marco 2013). This may be common in negative-politeness contexts characterised by social distance, lack of familiarity or power-differences, or, in other words, in deferential or hierarchical politeness systems (Scollon and Scollon 1995). However, this use may also be observed in solidarity politeness systems:

(7) ¡Dame un cigarrito!

'Give me a ciggy!'

Owing to this wealth of functions, the interpretation of the diminutive is often highly contingent on situational and discourse factors, such as the interlocutors' identities, relationships, intentions, previous knowledge or ways of speaking (Würstle 1992: 50). Moreover, their fulfilment reveals that its semantics cannot be constantly and invariably matched to notions like small size or low degree. For example, the speaker of (1a) would not be understood as communicating that the room in question is not very clean or that its level of cleanness is minimal. Similarly, that of (3a) would not be taken to state that the person referred to was wearing a small shirt or that the flowers printed on it were tiny. If the diminutive cannot be associated with those notions, what concept(s) would it encode? Or, rather, would it encode (a) concept(s) at all? Would it be a conceptual element?

An extant proposal argues that the diminutive morpheme would encode some sort of "[fictive]" feature. This would enable it to specify the referent of the word to which it is attached in a "[non-serious]" way, or perhaps in a non-literal manner (Dressler and Merlini Barbaresi 2001). If this was so, its semantics could then be accounted for as triggering more specific concepts than those encoded or activated by the lexical items to which it is added. The issue is that such concepts need not always be non-serious or non-literal, but could instead be highly personal. In other words, the speaker could take advantage of the diminutive morpheme in order to refer to highly idiosyncratic, perhaps context-specific notions. For instance, when she uses it with a view to intensifying, as in (1a), she would clearly not be alluding to a low level of cleanness, but to the opposite -i.e., a "non-literal notion". But the speaker could even mean a higher level of cleanness than expected or a special kind thereof. She might also be simultaneously expressing surprise or satisfaction with the (kind of) cleanness of the room. Then, instead of providing some size-, amount-, degree-related notional material, the diminutive would invite the creation or activation of some conceptual representation that could capture what the speaker is thought to mean. Similarly, when the speaker adds the diminutive in order to show her attitude towards something or express her emotions, as in (4), she would evidently not be pointing out the smallness of the house. However, she would not be suggesting that it is large, either; her intention would be for the hearer to notice that she has a certain attitude towards it or that it causes her a particular emotion, which he would have to represent mentally. 
This suggests that the diminutive would not contribute precise, stable conceptual representations to comprehension, so its role should be different. It seems to guide comprehension, and perhaps in distinct manners, during the process of formulation of a hypothesis about speaker's meaning. The issues that need solving are, therefore, what the nature of the diminutive is and what its actual impact on comprehension would be. These issues may be approached from a relevancetheoretic perspective. Indeed, relevance theory (Sperber and Wilson 1986/1995, Wilson and Sperber 2002, 2004) offers a psychologically plausible model of comprehension that is based on a series of parallel inferential tasks. Hypotheses about speaker-intended meaning depend on the output of such tasks, which could somehow be guided by the diminutive.

\section{Comprehension and mutual parallel adjustment}

Utterances are intentional ostensive stimuli that "make evident to the receiver the intention of the communicator to make it evident that she intends to inform the receiver of something. So an addressee is justified in expecting some significance from ostensive stimuli that he cannot expect from non-ostensive stimuli which he may attend to" (Carston 2013: 272-273). They set in motion a complex mental machinery that works out such significance by formulating a hypothesis about the speaker's meaning, or her informative intention (Wilson 2017). This usually is "not one particular interpretation, but any one of a number of interpretations with very similar import" (Carston 2000: 10).

Formulation of that hypothesis partially depends on decoding. The linguistic sub-module unpacks the constituents of utterances and arranges them in a logical form, or a chunk of conceptual representations. This form is "in the appropriate format for integration with representations from other information sources" (Carston 2000: 6), but is not yet fully propositional. It needs to undergo a series of inferential developments or pragmatic enrichments known as mutual parallel adjustment. They are carried out by the inferential mechanism (Sperber and Wilson 1995: 72, 181, Carston 2000, 2002, Wilson and Sperber 2002, 2004). One of them is disambiguation of the potential senses of lexical items -e.g., 'bank' as a financial institution or river shore- and/or of specific sentential constituents - e.g., "Can I try [that dress [that is] in the shop window]?" vs. "Can I try [that dress] [in the shop window]?". The other developments fall into two categories: those that are linguistically mandated and those that are not (Carston 2000, Jary 2016).

Linguistically mandated inferential developments are also known as saturation (Recanati 1993, 2002, 2004). They amount to assignment of reference to elements like personal, anaphoric or cataphoric pronouns, place and time deictics, or proper nouns, and assignment of temporal reference to verbs. These tasks are constrained by the procedures that such elements encode (Blakemore 1987, 1992, 2002, Wilson \& Sperber 1993, 2002, 2004). Thus, a personal pronoun like 'she' encodes an instruction that limits the searching space for a referent to a feminine and singular 
one, while the procedural meaning of a deictic like 'here' restricts the search for a location to one in the vicinity of the speaker. In turn, the Spanish or French imperfect preterite encode an instruction that sets an action in a long timespan prior to the moment of speaking (Escandell Vidal and Leonetti 2011, de Saussure 2012, Moeschler 2016).

Saturation is also necessary for completing syntactically complete but semantically sub-propositional sentences (Carston 2000, 2002, 2009, Carston and Hall 2017, Hall 2017):

(8) a. London is more beautiful [than what?]

b. It is the same [as what?]

Moreover, it is needed for establishing certain relations - e.g., temporal, causal, etc.- between events and states alluded to in a proposition. In this case, it may be aided by contextual or encyclopaedic information, and/or the procedures encoded by some discourse or pragmatic markers:

(9) Mary gave John a pen and [then/as a result] he wrote down her address.

Non-linguistically mandated developments of a logical form are known as free enrichment. They are made when "a proposition would be expressed by the saturated linguistically encoded meaning of the utterance, but the resulting proposition is not a fully explicit expression of what is asserted by the speaker" (Jary 2016: 25). They involve two operations:

(i) Supplying unarticulated constituents -i.e., aphonic or non-verbalised constituents necessary to get a meaningful proposition (Carston 2000: 3)- such as the location or time of an event, or the instrument wherewith an action is performed:

(10) a. There are seven packets [in the warehouse/shop]

b. I have had a shower [today/five minutes ago]

c. Tom gave Mary the key and [then] she opened the door [with the key that Tom gave her].

This development is a by-product of "general and routine processes of reasoning" (Carston 2000: 35) based on general knowledge about actions and events. It is not triggered by covert, silent or hidden indexicals, or empty constituent slots (Recanati 1989, Stanley 2000, 2002, Stanley \& Szabó 2000, Martí 2006).

(ii) Lexical adjustment. Relevance-theoretic pragmatics conceives of concepts as mental entities consisting of a lexical entry with information about the natural language words used to verbalise them, a logical entry with inference rules capturing its analytic implications and an encyclopaedic entry storing varied information about their denotation. Initially, concepts were claimed to be encoded by open-class words like nouns, adjectives and verbs, and to have a denotation. But they were also argued to be schematic, to amount to pro-concepts. Hence, they were thought to need an inferential adjustment resulting in occasion-specific or ad hoc concepts (Sperber and Wilson 1997, Carston 2000, 2002). A verb like 'pass' in the 
sentences below would encode the concept $\mathrm{PASS}^{3}$, but it needs modulating in differing manners so that it denotes distinct, albeit somehow related, actions (from Carston 2013):

(11) a. Jack passed a rope around the tree.

b. Jill passed two cars.

c. Jack passed Jill his phone number.

d. Mary passed her exams.

Early on, relevance-theoretic pragmatics distinguished two types of lexical adjustment (Carston 2000, 2002, Wilson and Carston 2006, 2007). The first one is broadening or loosening of the denotation of a concept towards something less specific than its literal meaning. This fine-tuning drops one or more of the logical or defining properties of the concept. Thus, CIRCLE in (12a) would not exactly denote a circular shape, but a circle-like shape, while RAW in (12b) would not mean literally raw, but undercooked (from Carston 2013):

(12) a. The children quickly formed a circle.

b. This steak is raw.

The second type is narrowing or strengthening of a lexicalised concept so that it refers to something more specific. This involves elevating one of its idiosyncratic properties to the status of logical property (Carston 2002: 339) on the grounds of "other concepts encoded in the uttered sentence and larger exchange, as well as contextual assumptions, contextually-salient objects, events, etc., and expectations about intended interpretations" (Hall 2017: 93). Accordingly, RED in (13a) is limited to 'red ink', while DRINK in (13b) is specified as "drinking large quantities of alcohol" (from Carston 2013):

(13) a. Give me a red pen.

b. Many doctors drink because of the stress of their job.

Both adjustments, nevertheless, may take place in combination. This happens, for example, when words are metaphorically used:

(14) Anne is a princess.

Lexical adjustment was then understood as a "rearrangement of some of the information associated with lexical concepts" (Hall 2017: 93). However, a more recent view posits that open-class words would not encode concepts, but just procedures ${ }^{4}$. These would enact the construction of "an address or file label giving access to associated information in memory" (Hall 2017: 97). Such a file would gather highly idiosyncratic information making up singular, perhaps one-off, mental entities (Carston 2013, 2016, Wilson 2016).

${ }^{3}$ Following another relevance-theoretic convention, concepts are notated in small caps and ad hoc concepts with an asterisk.

${ }^{4}$ Conceptual and procedural meaning need not be mutually exclusive but may be jointly encoded by some linguistic expressions (Ifantidou 1992, 1993, Escandell Vidal 2002, Wilson and Sperber 1993, Wharton 2009, Wilson 2016). 
These pragmatic developments follow the least effort-demanding path and stop when expectations of cognitive gain are satisfied. Relying on highly salient contextual and encyclopaedic information, the mind looks for the most easilyaccessible, logical and plausible options when delimiting the sense of words or syntactic stretches, searching for potential referents, recovering missing information or modulating the meaning of lexical items (Wilson 1999, 2017, Wilson \& Sperber 2002, 2004). The result is the lower-level explicature of an utterance. This is part of the meaning that the speaker communicates explicitly. It has four defining characteristics:

a) It is a communicated proposition that is part of the speaker's meaning.

b) It is identified by a combination of decoding and inference. The more decoding involved, the stronger a lower-level explicature will be, while the more inference needed, the weaker it will be (Wilson and Sperber 2002, 2004, Wilson 2017).

c) It is distinct from an implicature, as it does not overlap in content and has its own truth conditions. In fact, a lower-level explicature can function as an autonomous premise in inferential processes and may be stored separately in memory (Carston 2013: 263-264).

d) Like an implicature, it is calculable and cancellable. Indeed, "cancellability and calculability are properties of any and all aspects of utterance meaning which are derived pragmatically rather than via a process of linguistic decoding" (Carston 2013: 264) .

The mind also represents the speaker's attitude, feelings, emotions and/or stance about what she says, and/or the action that she intends to perform verbally. This representation is the higher-level explicature. It is a conceptual schema under which the pragmatically developed logical form is embedded (Sperber and Wilson 1986/1995, Wilson and Sperber 2002, 2004). Its construction may be steered by a plethora of linguistic elements. These include attitudinal adverbials (15), illocutionary adverbials (16), evidential adverbials (17), hearsay adverbials (18), parenthetical expressions (19), syntax, mood and/or modal verbs (20) (Ifantidou 1992, 1993, 2001, Wilson and Sperber 1993, Wilson 1999):

(15) a. Unfortunately, Tom did not enjoy the film.

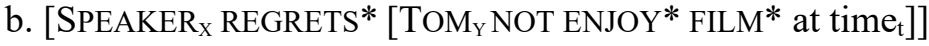

(16) a. Frankly, Tom enjoyed the film.

b. [SPEAKER SAYS* IN A FRANK MANNER [TOM $_{\mathrm{Y}}$ ENJOY* FILM* at $^{*}$ time $t]$ ]

(17) a. Clearly, Tom enjoyed the film.

b. [SPEAKER IS CERTAIN* [TOM $_{\mathrm{Y}}$ ENJOY* FILM* at time $\left._{\mathrm{t}}\right]$ ]

${ }^{5}$ To Gricean pragmatists, cancellability was a feature of the so-called particularised conversational implicatures. Presuppositions or conventional implicatures, in contrast, were considered non-cancellable because of their dependence on the semantic properties of one or some of the words used (Grice 1989). 
(18) a. Allegedly, Tom enjoyed the film.

b. [SPEAKER IS UNCERTAIN* $^{*}$ [TOM ENJOY* FILM* $^{*}$ at time $\left.\mathrm{t}\right]$ ]

a. Tom did not enjoy the film, I hear.

b. [SPEAKER HEARS*/IS TOLD* [TOMY ENJOY* FILM* at time $_{\mathrm{t}}$ ]]

(20) a. Tom enjoyed/might have enjoyed the film.

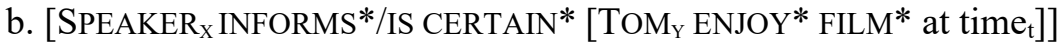

Paralinguistic elements like interjections, prosody, gestures, facial expressions or movements also assist the construction of higher-level explicatures, as they also encode processing instructions (Wilson and Wharton 2006, Wharton 2009, 2016). If they provide clear evidence for the speaker's attitude, stance, emotions or feelings, they determinately show it, while they indeterminately do so if the evidence that they provide is less clear (Sperber and Wilson 2015):

(21) a. Wow, Tom enjoyed the film!

b. [SPEAKER $\mathrm{X}$ IS HAPPY*/SURPRISED*/DELIGHTED* [TOMY ENJOY* FILM $^{*}$ at time $\left.t\right]$

Absent in Gricean pragmatics, the notion of higher-level explicature is a valuable contribution of relevance-theoretic pragmatics. It also has four defining characteristics:

a) It is not the communicated proposition, but a representation, perhaps in a propositional format, of the speaker's mental states. Yet, it also is part of her informative intention.

b) It is identified by a combination of decoding, inference and emotion-reading in some cases, while in others by inference and emotion-reading. Its strength varies depending on the number of mechanisms involved in its construction and the determinacy of paralanguage.

c) It is distinct from a lower-level explicature and occupies a superordinate representational level, as it subsumes the latter.

d) It is calculable and cancellable inasmuch as its construction relies on inference and this may go wrong.

Both the lower- and the higher-level explicature make up the explicit content of an utterance. The fact that the diminutive morpheme may be connected with specific notions could indicate that it contributes some conceptual material to the explicit content of utterances. Then, it would be a conceptual element. However, its varied usages also suggest that its contribution to comprehension could be different: it could steer (some of) the tasks in mutual parallel adjustment and it could do so in distinct manners. It seems to affect other conceptual elements in the lower-level explicature of an utterance, but it might trigger the representation of the speaker's attitude, emotions and/or feelings. This would involve admitting that the diminutive is a procedural element that steers the phase of comprehension in which hypotheses about explicit content are formulated. 


\section{On the procedural nature of the diminutive morpheme}

If the semantics of the diminutive morpheme were conceptual, it would encode concepts like smallness or littleness. Consequently, it would alter the denotation of the concept linguistically encoded by the word to which it is attached in terms of size. For instance, its addition to a noun like 'dog' would shift the concept DOG encoded by that noun to another like SMALL DOG. This would have facilitated the lexicalisation of words receiving this morpheme, as might have happened to 'mesita/mesilla de noche' ('nightstand') (Criado de Diego and Andión Herrero 2018).

This semantic modification, however, does not seem feasible when the diminutive expresses intensification (1), approximation (2) and pejoration (3), or when it is used to show intimacy (5) or modesty (6). The speaker of (1a) would not be communicating that the degree of cleanness of the room is low, while that of (2a) would not be saying that the town is not (very) close. The adjective to which the diminutive is attached in (1a) seems to express a higher degree of cleanness than average or than the speaker actually expected, about the same as the adverb in (2a) appears to convey that the town is close, closer than expected or within a short ride. Similarly, in (3a) the speaker would not be stating that the shirt and the flowers on it are tiny, while in (5) she would not be calling her interlocutor a miniature bastard. The nouns to which the diminutive is added in (3a) give the impression that the shirt is hideous or of bad quality, and the flowers on it outdated or of bad taste. In turn, in (5) the diminutive shows that the speaker considers her interlocutor any of a range of things including a rascal, a naughty person or a badly behaved person, while it also displays her affection to him. Lastly, the speaker of (6) would not be asserting that her new car is minuscule, either. The morpheme suggests that the speaker's car is affordable, inexpensive, non-indulgent, an average or sub-compact vehicle.

None of those notions or ideas are objectively connected with size, but involve some element of subjectivity. What speakers seem to do when adding the diminutive is to invite the construction of highly idiosyncratic conceptual representations that capture personal assessments, estimates, judgements or evaluations of something to which they allude. Accordingly, the diminutive would trigger the construction of the ad hoc, occasion-specific, perhaps one-off, concepts LIMPIA* (CLEAN*), CERCA* (CLOSE*), CAMISA* (SHIRT*), etc. It would be endowed with a procedural semantics enacting the adjustment of the concepts encoded by the words to which it is attached. Hence, instead of contributing conceptual material to comprehension, its contribution would amount to processing instructions steering lexical pragmatic processes.

Following the traditional relevance-theoretic view of lexical adjustment, the procedural semantics of the diminutive would instruct the comprehension module to narrow down the denotation of the concept encoded by the word to which it is added towards some more specific notional space. The logical properties of that concept would be retained, but one or more items of encyclopaedic information 
would be elevated to defining properties, even if temporarily. In the case of (3a), for instance, the encyclopaedic entry of CAMISA (SHIRT) might store beliefs concerning features or properties related to size, material, cut, style, touch, etc., as well as more personal beliefs regarding the speaker's views, values or standards about shirts in general or some type or style of shirt. When the denotation of that concept is narrowed, some of those personal beliefs are given the status of essential properties of the resulting concept. Thus, CAMISA* (SHIRT*) might be roughly paraphraseable as "outdated loose-fitting shirt that the speaker dislikes and would never wear". The final output of narrowing, nevertheless, would depend on available contextual information and, obviously, on the information stored in the encyclopaedic entry of the concept encoded by the lexical item to which the diminutive is attached. In the more recent relevance-theoretic view, in contrast, the procedure encoded by the diminutive would trigger the creation of some sort of occasional mental file where the hearer stores beliefs about what he thinks the speaker refers to by means of the lexical item to which the morpheme is added. Thus, CAMISA* (SHIRT*) might host beliefs pertaining to the type of garment the speaker means, its cut, size, style, decoration, but also similar beliefs concerning the speaker's supposed opinion or assessment of the shirt she is talking about.

Ascribing this procedural semantics to the diminutive, however, might raise certain issues when it is used to express attitudes, emotions or feelings. Certainly, the ad hoc concepts resulting from its addition may house beliefs about the speaker's likes, preferences, assessments, judgements and, why not, the attitudes she has towards the referents of such concepts or the emotions that they cause her. When processing (4), the hearer might create the ad hoc concept CASA* (HOUSE*), roughly paraphraseable, for instance, as "the sort of house the speaker likes/adores". Its mental file might likewise include fairly idiosyncratic assumptions to the effect that the speaker is delighted, impressed, surprised, stunned or dumbfounded by the house. Yet, the representation of affective attitudes and emotions seems to be the by-product of a specialised emotion-reading mechanism different from the inferential one (Wilson 2012).

The emotion-reading mechanism monitors a variety of paralinguistic clues and is thought to yield some sort of attitudinal or emotional description. The format of this representation would be compatible with that of the representations constructed by the inferential mechanism, so it can integrate with them. The occurrence of the diminutive morpheme might be considered to activate, or raise the activation of, the emotion-reading mechanism. Additionally, it might be deemed to somehow constrain the output of that mechanism in a fashion similar to attitudinal adverbials and paralinguistic clues like interjections, intonation, facial expressions or gestures.

The descriptions enacted by such (para)linguistic elements embed or subsume the whole pragmatically developed proposition supplied by the inferential mechanism. In other words, their scope ranges over a whole lower-level explicature. In contrast, the attitudinal or emotional representations that the diminutive might be supposed to trigger would not take under their scope whole 
propositions. Rather, they would simply affect constituents thereof: namely, the conceptual referents of the lexical items to which the diminutive is attached. This would enable the diminutive to indicate the speaker's attitude or feelings about just certain constituents of a propositional form, not about the whole of it. As in the case of higher-level explicatures, the actual content of that alleged representation would depend on available contextual and/or encyclopaedic information. If this were so, then the diminutive morpheme could also be contended to encode another procedure: one that facilitates identification of psychological states about entities, objects, events, etc., referred to in a proposition, and their mental representation. That new representation could be sketched as follows:

(22) a. Tienes una casita muy acogedora.

b. [SPEAKER SAYS $^{*}\left[\right.$ HEARER $_{Y}$ OWNS* COSY* [ [SPEAKER FEELS POSTTIVE EMOTION $>$ HOUSE*]]

The output of that procedure would resemble that of the procedures that slurs or expressive expletives might encode. Offensive terms like 'hori' or 'chink' target a disparaging attitude at the social group that they allude to (Blakemore 2015). They could then be posited to enact its representation through some attitudinal description confined to their referents. In turn, expletives like 'fucking' or 'bleeding' project a number of attitudes towards the nouns they accompany. They would hence trigger similar mental representations, too (Padilla Cruz 2018, 2019). Output similarity might warrant an alternative procedural analysis of the diminutive along the same lines as these two types of elements.

The more restricted scope of the attitudinal or emotional description that the diminutive, as well as slurs and expletives, might trigger would differentiate it from a higher-level explicature. Supposedly, it would occupy a different representational slot or give rise to an additional representational layer. That attitudinal or emotional description would only subsume, or be superordinate to, a conceptual constituent of a lower-level explicature. This might apparently justify coining a new label in order to refer to it: intermediate-level explicature (Padilla Cruz 2018). An intermediate-level explicature could be characterised as follows:

a) It would be a representation, perhaps in a propositional format too, of the speaker's affective attitude towards or emotional state about what is denoted by a conceptual element of the proposition that she expresses. Hence, it would also be part of her intended meaning.

b) It would be the by-product of decoding, inference and emotion-reading, and its strength would be contingent on the occurrence of (para)linguistic elements steering its construction. These could provide more or less clear evidence of the speaker's psychological states.

c) It would be distinct from both a lower-level and a higher-level explicature, as it would only take under its scope a constituent of a lower-level explicature. Therefore, it would be a shorter-ranging representation whose scope is limited to just a conceptual element of the expressed proposition. 
d) Like a lower-level and a higher-level explicature, it would also be both calculable and cancellable because of its dependence on inference.

The ascription of that alternative procedure triggering that shorter-ranging attitudinal or emotional representation to the diminutive morpheme would also raise a series of issues. On the one hand, the diminutive would be a poly-procedural element: it would encode a procedure for ad hoc-concept construction and another procedure enacting the said representation, which would be activated on differing occasions. The possibility that certain linguistic elements encode more than one procedure has been advanced by Padilla Cruz $(2018,2019)$ and Bardzokas $(2019 \mathrm{a}$, 2019b). The former has proposed that expressive expletives might enact ad hocconcept construction, while giving rise to affective-attitude descriptions. The latter has argued that the Modern Greek pragmatic marker ' $\mu \alpha$ ' ('ma') effects the elimination of a contextual assumption accessed by the hearer and the representation of the speaker's attitude of surprise about that assumption. Similarly, ' $\alpha \varphi$ ov' ('afú') constrains the implicated content of the utterance where it appears and presents a convincing argument justifying a speaker's decision to perform a speech act. Such a twofold procedural encoding would contradict the current relevance-theoretic characterisation of procedural meaning. In addition to being non-compositional, behaving rigidly and lacking nonliteral uses, procedural elements are claimed to be monosemic: they only encode one processing instruction (Carston 2016: 159-161). However, multiple procedural encoding would be possible if the diminutive encoded some sort of meta-procedure, or superordinate instruction, determining which particular procedure from among a set of candidates should be activated in a specific context. Alternatively, the activation of a specific procedure could be determined by additional semantic, syntactic or prosodic constraints (Wharton 2009, Wilson 2011, 2012, 2016, Padilla Cruz 2018).

On the other hand, the enactment of another representational layer would increase the complexity of the tasks in mutual parallel adjustment and, therefore, cognitive effort. That increase undoubtedly contravenes the natural tendency of the human mind to achieve maximum processing efficiency (Sperber and Wilson 1986/1995). Its by-product, furthermore, might be considered to superfluously increment the number of representations with which the mind would work. This would oppose Ockham's razor principle, according to which the simplest and easiest explanation is to be preferred. Perhaps information about the speaker's attitude, emotions or feelings may be manifest as a result of the occurrence of the diminutive morpheme and can be stored within the conceptual file created for the lexical item to which it is attached (Padilla Cruz, in press). However, there does not seem to be any reason why the mind could not be thought to represent that information as an additional, independent representation. It could be the output of the emotion-reading mechanism, which would track paralinguistic clues like prosody, facial expressions or gestures accompanying the utterance where the diminutive occurs (Wilson 2012). Were this so, the diminutive would contribute to 
the activation of that mechanism, interact with those clues and favour the construction of such a representation.

The procedural semantics of the diminutive has thus far been examined with regard to its uses as an intensification, approximation or pejoration device, as well as when it shows intimacy or psychological states. But this morpheme also satisfies an attenuating, hedging or mitigating function (Garcés Conejos, Bou Franch and García Gómez 1992, Albelda Marco and Briz Gómez 2010, Albelda Marco and Cestero Mancera 2011, Briz Gómez 2011, Briz Gómez and Albelda Marco 2013, Maíz-Arévalo 2018). In directive speech acts, such as requests, commands or orders, it communicates that the very action, or a requested item, do not involve a high degree of imposition (Brown and Levinson 1987). This function might suggest that its semantics resists a procedural analysis along the lines of those previously proposed.

Clearly, the diminutive would not give rise to an additional representation capturing the speaker's psychological states about something. Indeed, she would not be expressing any feeling about something she alludes to. As for lexical adjustment, the diminutive might be thought not to license it either. In (7) the morpheme would not effect the narrowing of CIGARETTE so that the fine-tuned concept highlights or brings to the fore specific properties or nuances of the referred item. The speaker simply unveils estimates about the cost of an object or action. The crux of the diminutive might then be deemed to reside precisely there: in what the speaker communicates about the action that she seeks to accomplish.

Representations of illocutionary force or actions verbally attempted are made through higher-level explicatures. The diminutive might be judged to constrain them when it is used to hedge speech acts. Its semantics would also be procedural and the procedure that it would allegedly encode would assist the construction of fine-grained superordinate speech-act descriptions. These might be considered to include precise information about the performance or presentation of the intended action, or the hearer's unlikely effort-expenditure. Thus, the notion of littleness or low degree often linked to the diminutive would be symbolically transferred to, and somehow integrated in, the higher-level explicature of an utterance -hence its capacity for mitigating verbal actions. Those more elaborate higher-level explicatures would somehow resemble those effected by the occurrence of illocutionary adverbials like that in (16). Accordingly, the higher-level explicature of (7) could be represented as follows:
a. [SPEAKER REQUESTS* POLITELY [HEARER $_{Y}$ GIVES* SPEAKER CIGARRETTE*]]
b. [SPEAKER $\mathrm{R}$ REQUESTS*, AND THINKS* THAT REQUEST* DOES NOT REQUIRE* (MUCH) EFFORT* [HEARER ${ }^{*}$ GIVES* ${ }^{*}$ SPEAKER CIGARRETTE*]]

Again, positing a procedure for only a specific use of the diminutive would render it a poly-procedural element and leave a complex picture of its semantics: in some cases it would steer the lexical pragmatic processes necessary for the 
construction of a lower-level explicature, in other cases it would facilitate the construction of attitudinal or emotional representations, whereas in others it would contribute to higher-level explicatures. Activation of that extra procedure would call for a superordinate procedure or depend on paralinguistic clues and/or linguistic factors, such as imperative mood, interrogative word-order, conventionalised (requestive) formulae and/or occurrence of certain illocutionary force indicating devices. Yet, this could be considered demanding and implausible in cognitive terms, and to contradict the relevance-theoretic position on procedural meaning. That third procedure could even be deemed redundant, as long as its effects could be thought to result from another procedure: that enacting ad hoc-concept construction. This might otherwise be regarded as the sole procedure encoded by the diminutive. If that pragmatic process were approached as a rearrangement of information stored in the encyclopaedic entry of a concept (Hall 2017), it would facilitate access to encyclopaedic assumptions referring to the cost of goods or actions, and their elevation to the status of defining properties, even if momentarily. If that process is approached as amounting to the creation of idiosyncratic mental spaces subsuming varied assumptions (Carston 2013, 2016, Wilson 2016), the instructions packed by the diminutive would trigger files that would house beliefs concerning the speaker's estimates of item cost or the effort-expenditure demanded by particular actions. Although this would enable a unitary account of the procedural meaning of this morpheme, it still is too soon to rule out the possibility that its semantics might consist of three procedures or it causes the mind to perform distinct tasks yielding diverse outputs. Future research should corroborate or refute it by examining the communicative effects of the diminutive in other languages where it is also fairly productive or by analysing the augmentative, another evaluative morpheme that appears to fulfil similar functions.

\section{Conclusion}

The various functions of the diminutive morpheme may be explained as stemming from its semantics. Though it is amenable to a procedural analysis, this is not an easy endeavour. This affix might be argued to encode distinct procedures: one for ad hoc-concept construction, another giving rise to shorter-ranging attitudeor emotion-related descriptions, and a third one steering the construction of sophisticated higher-level explicatures. They would turn the morpheme into a polyprocedural element requiring an additional instruction or (para)linguistic constraints determining the exact procedure that should be activated on a particular occasion. Alternatively, the procedural meaning of the diminutive could be viewed as consisting solely of one processing instruction. It would only effect a lexical pragmatic process resulting in an occasion-specific conceptual representation that may store a range of information. That information may pertain to the speaker's attitudes, emotions and feelings about what she alludes to, or the cost and/or effortexpenditure demanded by items or actions. Although approaching the semantics of this morpheme in this fashion would enable a unitary account of its meaning and 
contribution to communication, further research should confirm the number and nature of the procedure(s) that the diminutive actually encodes. This is fundamental to developing a psychologically plausible relevance-theoretic approach to this evaluative morpheme.

(C) Manuel Padilla Cruz, 2020 @creative

This work is licensed under a Creative Commons Attribution 4.0 International License https://creativecommons.org/licenses/by/4.0/

\section{REFERENCES}

Albelda Marco, Marta \& Antonio Briz Gómez. 2010. Aspectos pragmáticos. Cortesía y atenuantes verbales en las dos orillas a través de muestras orales. In Milagros Aleza Izquierdo \& José María Enguita Utrilla (eds.), La lengua española en América: normas y usos actuales, 237-260. Valencia: Universidad de Valencia.

Albelda Marco, Marta \& Ana María Cestero Mancera. 2011. De nuevo, sobre los procedimientos de atenuación lingüística. Español Actual 96. 9-40.

Badarneh, Muhammad A. 2010. The pragmatics of diminutives in colloquial Jordanian Arabic. Journal of Pragmatics 42 (1). 153-167.

Bardzokas, Valandis. 2019a. Distinctions in procedural meaning. International Review of Pragmatics 11 (1). 79-108.

Bardzokas, Valandis. 2019b. Poly-procedural meaning: The case of Modern Greek marker 'afu'. Paper delivered at the $40^{\text {th }}$ Annual Meeting. Department of Linguistics, School of Philology, Aristotle University of Thessaloniki.

Blakemore, Diane.1987. Semantic constraints on relevance. Oxford: Basil Blackwell.

Blakemore, Diane.1992. Understanding utterances. An introduction to pragmatics. Oxford: Blackwell.

Blakemore, Diane. 2002. Relevance and linguistic meaning. The semantics and pragmatics of discourse markers. Cambridge: Cambridge University Press.

Blakemore, Diane. 2011. On the descriptive ineffability of expressive meaning. Journal of Pragmatics 43 (14). 3537-3550.

Blakemore, Diane. 2015. Slurs and expletives: A case against a general account of expressive meaning. Language Sciences 52. 22-35.

Bosque, Ignacio. 2009. Nueva gramática de la lengua española. Madrid: Espasa.

Briz Gómez, Antonio. 2011. Lo discursivo de las partículas discursivas en el Diccionario de partículas discursivas del español (DPDE): La atenuación como significado fundamental o uso contextual. In Heidi Aschenberg \& Óscar Loureda Lamas (eds.), Marcadores del discurso: de la descripción a la definición, 77-108. Madrid: Iberoamericana.

Briz Gómez, Antonio \& Marta Albelda Marco. 2013. Una propuesta teórica y metodológica para el análisis de la atenuación lingüística en español y portugués. La base de un proyecto en común (ES.POR.ATENUACIÓN). Onomázein 28 (2). 288-319.

Brown, Penelope \& Stephen C. Levinson. 1987. Politeness: Some universals in language usage. Cambridge: Cambridge University Press.

Carston, Robyn. 2000. Explicatures and semantics. UCL Working Papers in Linguistics 12. 1-44.

Carston, Robyn. 2002. Thoughts and utterances. The pragmatics of explicit communication. Oxford: Blackwell. 
Carston, Robyn. 2009. The explicit/implicit distinction in pragmatics and the limits of explicit communication. International Review of Pragmatics 1 (1). 35-62.

Carston, Robyn. 2013. Word meaning, what is said and explicatures. In Carlo Penco \& Filippo Domeneschi (eds.), What is said and what is not, 175-204. Stanford: CSLI.

Carston, Robyn. 2016. The heterogeneity of procedural meaning. Lingua 175-176. 154-166.

Carston, Robyn \& Alison Hall. 2017. Contextual effects on explicature: Optional pragmatics or optional syntax? International Review of Pragmatics 9 (1). 51-81.

Criado de Diego, Cecilia \& Andión Herrero, María Antonieta. 2018. Lexicalización diminutiva en dos corpus originales (lengua oral y lengua escrita). Estudios de Lingüistica de la Universidad de Alicante 32. 73-90.

De Marco, Anna. 1998. The acquisition of diminutives in Italian. Antwerp Papers in Linguistics 95. 199-218.

de Saussure, Louis. 2012. Temporal reference in discourse. In Keith Allan \& Kasia Jaszcolt (eds.), The Cambridge handbook of pragmatics, 423-446. Cambridge: Cambridge University Press.

Dressler, Wolfgang U. \& Lavinia Merlini Barbaresi. 2001. Morphopragmatics of diminutives and augmentatives. On the priority of pragmatics over semantics. In István Kenesei \& Robert M. Harnish (eds.), Perspectives on semantics, pragmatics, and discourse. Festschrift for Ferenc Kiefer, 43-58. Amsterdam: John Benjamins.

Escandell Vidal, Victoria. 2002. Echo-syntax and metarepresentations. Lingua 112 (11). 871-900.

Escandell Vidal, Victoria \& Manuel Leonetti. 2011. On the rigidity of procedural meaning. In Victoria Escandell Vidal, Manuel Leonetti \& Aoife Ahern (eds.), Procedural meaning: Problems and perspectives, 81-102. Bingley: Emerald Group Publishing,

Fraser, Bruce. 1990. Perspectives on politeness. Journal of Pragmatics 14. 219-236.

Garcés Conejos, Pilar, Bou Franch, Patricia \& Emilio García Gómez. 1992. Estudio pragmático-contrastivo del diminutivo: Una propuesta metodológica. In Feli Etxeberria \& Jesús Arzamendi (eds.), Bilingüismo y adquisición de lenguas. Actas del IX Congreso Nacional de AESLA, 247-258. Vitoria: Servicio de Publicaciones de la Universidad del País Vasco.

Gómez Torrego, Leonardo. 2002. Gramática didáctica del español. Madrid: Ediciones SM. Grice, Herbert P. 1989. Studies in the Way of Words. Cambridge: Harvard University Press. Hall, Alison. 2017. Lexical pragmatics, explicature and ad hoc concepts. In Ilse Depraetere \& Raphael Salkie (eds.), Semantics and pragmatics: Drawing a line, 85-100. Cham: Springer.

Ifantidou, Elly. 1992. Sentential adverbs and relevance. UCL Working Papers in Linguistics 4. 193-214.

Ifantidou, Elly. 1993. Parentheticals and relevance. UCL Working Papers in Linguistics 5. 193210.

Ifantidou, Elly. 2001. Evidentials and relevance. Amsterdam: John Benjamins.

Jary, Mark. 2016. Rethinking explicit utterance content. Journal of Pragmatics 102. 24-37.

Locher, Miriam A. \& Richard J. Watts. 2005. Politeness theory and relational work. Journal of Politeness Research. Language, Behaviour and Culture 1 (1). 9-33.

Maíz-Arévalo, Carmen. 2018. "Sólo un poquito": El uso y funciones del diminutivo en español peninsular en dos grupos de Facebook. Círculo de Lingüística Aplicada a la Comunicación 73. 33-52.

Martí, Luisa. 2006. Unarticulated constituents revisited. Linguistics and Philosophy 29 (2). $135-166$. 
Mendoza, Martha. 2005. Polite diminutives in Spanish. A matter of size? In Robin T. Lakoff \& Sachiko Ide (eds.), Broadening the horizons of linguistic politeness, 163-173. Amsterdam: John Benjamins.

Moeschler, Jacques. 2016. Where is procedural meaning located? Evidence from discourse connectives and tenses. Lingua 175-176. 122-138.

Náñez Fernández, Emilio. 2006. El diminutivo. Historia y funciones en el español clásico y moderno. Madrid: Universidad Autónoma de Madrid.

Padilla Cruz, Manuel. 2018. Expressive APs and expletive NPs revisited: Refining the extant relevance-theoretic procedural account. Lingua 205. 54-70.

Padilla Cruz, Manuel. 2019. Qualifying insults, offensive epithets, slurs and expressive expletives: A relevance-theoretic approach. Journal of Language Aggression and Conflict 7 (2). 156-181.

Padilla Cruz, Manuel (in press) Ad hoc concepts, affective attitude and epistemic stance. Pragmatics \& Cognition.

Potts, Christopher. 2007a. The expressive dimension. Theoretical Linguistics 33 (2). 165-197.

Potts, Christopher. 2007b. The centrality of expressive indices. Theoretical Linguistics 33 (2). 255-268.

Recanati, François. 1993. Direct reference: From language to thought. Oxford: Blackwell.

Recanati, François. 2002. Does linguistic communication rest on inference? Mind \& Language 17 (1-2). 102-126.

Recanati, François. 2004. Literal meaning. Cambridge: Cambridge University Press.

Schneider, Klaus P. 2003. Diminutives in English. Tübingen: Max Niemeyer Verlag.

Scollon, Ron \& Suzanne W. Scollon. 1995. Intercultural communication. A discourse approach. Cambridge: Blackwell.

Sifianou, Maria. 1992. The use of diminutive in expressing politeness: Modern Greek versus English. Journal of Pragmatics 17 (2). 155-173.

Spencer-Oatey, Helen D. (eds.). 2008. Culturally speaking. Culture, communication and politeness. London: Continuum.

Sperber, Dan \& Deirdre Wilson. 1986. Relevance. Communication and cognition. Oxford: Blackwell.

Sperber, Dan \& Deirdre Wilson. 1995. Relevance. Communication and cognition (2 ${ }^{\text {nd }}$ ed.). Oxford: Blackwell.

Sperber, Dan \& Deirdre Wilson. 1997. The mapping between the mental and the public lexicon. UCL Working Papers in Linguistics 9. 107-125.

Sperber, Dan \& Deirdre Wilson. 2015. Beyond speaker's meaning. Croatian Journal of Philosophy 15 (44). 117-149.

Stanley, Jason. 2000. Context and logical form. Linguistics and Philosophy 23 (4). 391-434.

Stanley, Jason. 2002. Making it articulated. Mind \& Language 17 (1-2). 149-168.

Stanley, Jason \& Zoltán G. Szabó. 2000a. On quantifier domain restriction. Mind \& Language 15 (2-3). 219-261.

Volek, Bronislava. 1987. Emotive signs in language and semantic functioning of derived nouns in Russian. Amsterdam: John Benjamins.

Wharton, Tim. 2009. Pragmatics and non-verbal communication. Cambridge: Cambridge University Press.

Wharton, Tim. 2016. That bloody so-and-so has retired: Expressives revisited. Lingua 175-176. 20-35.

Wierzbicka, Anna. 1991. Cross-cultural pragmatics. The semantics of human interaction. Berlin: Mouton de Gruyter.

Wilson, Deirdre. 1999. Metarepresentation in linguistic communication. UCL Working Papers in Linguistics 11. 127-161. 
Wilson, Deirdre. 2012. Modality and the conceptual-procedural distinction. In Ewa Wałaszewska \& Agnieszka Piskorska (eds.), Relevance theory. More than understanding, 23-43. Newcastle: Cambridge Scholars Publishing.

Wilson, Deirdre. 2016. Reassessing the conceptual-procedural distinction. Lingua 175-176. 5-19.

Wilson, Deirdre. 2017. Relevance theory. In Yan Huan (eds.), The Oxford handbook of pragmatics. Oxford: Oxford University Press.

Wilson, Deirdre \& Robyn Carston. 2006. Metaphor, relevance and the 'emergent property' issue. Mind \& Language 21 (3). 404-433.

Wilson, Deirdre \& Robyn Carston. 2007. A unitary approach to lexical pragmatics: Relevance, inference and ad hoc concepts. In Noel Burton-Roberts (eds.), Pragmatics, 230-259. Basingstoke: Palgrave.

Wilson, Deirdre \& Dan Sperber. 1993. Linguistic form and relevance. Lingua 90 (1). 1-25.

Wilson, Deirdre \& Dan Sperber. 2002. Relevance theory. UCL Working Papers in Linguistics 14. 249-287.

Wilson Deirdre \& Dan Sperber. 2004. Relevance theory. In Larry Horn \& Gregory Ward (eds.), The handbook of pragmatics, 607-632. Oxford: Blackwell.

Wilson, Deirdre \& Tim Wharton. 2006. Relevance and prosody. Journal of Pragmatics 38. $1559-1579$.

Würstle, Regine. 1992. Überangebot und Defizit in der Wortbildung: Eine kontrastive Studie zur Diminutivbildung im Deutschen, Französischen und Englischen. Frankfurt am Main: Peter Lang.

Zuluaga Ospina, Alberto. 1970. La función del diminutivo en español. Thesaurus 1 (1). 23-48.

Article history:

Received: 30 July 2020

Revised: 30 September 2020

Accepted: 2 October 2020

\section{История статьи:}

Дата поступления в редакцию: 30 июля 2020

Дата принятия к печати: 2 октября 2020

\section{Bionote:}

Manuel PADILA CRUZ holds a PhD in English Linguistics from Universidad de Seville, where he currently is an Associate Professor of English at the Department of English Language. He also is the head of the research group "Intercultural pragmatic studies (English-Spanish): Pragmatic and discourse issues". His research interests fall within pragmatics and, more specifically, relevance-theoretic pragmatics. He has approached a number of phenomena that include phatic communication, interjections, pragmatic failure, insults, epistemic vigilance or humour. His work has been published, among others, in Journal of Pragmatics, Intercultural Pragmatics, International Review of Pragmatics, Humor, Lingua, Language Awareness, and International Review of Applied Linguistics in Language Teaching.

\section{Contact information:}

University of Seville, Seville, Spain

e-mail:mpadillacruz@us.es

ORCID ID: 0000-0003-2908-7261 


\section{Сведения об авторе:}

Мануэль ПАДИЛЬЯ КРУЗ получил докторскую степень по лингвистике английского языка в Университете Севильи, где в настоящее время является доцентом кафедры английского языка. Он возглавляет исследовательскую группу «Межкультурные прагматические исследования (английский - испанский языки): прагматические и дискурсивные проблемы». Сферу его исследовательских интересов составляют проблемы прагматики, в частности, прагматические аспекты теории релевантности. Доктор Падилья Круз исследовал ряд лингвистических феноменов, в т.ч. фатическое общение, междометия, прагматические сбои, оскорбления, эпистемическую вигильность и юмор. Его работы были опубликованы в журналах Journal of Pragmatics, Intercultural Pragmatics, International Review of Pragmatics, Humor, Lingua, Language Awareness, International Review of Applied Linguistics in Language Teaching.

Контактная информация:

University of Seville

e-mail: mpadillacruz@us.es

ORCID ID: 0000-0003-2908-7261 